\title{
Preface
}

\section{Biên Hòa Cemetery}

The cemetery wasn't much to look at. Broken slabs of concrete covered many of the graves. Some were tilted, threatening to fall onto the caskets beneath. The scraggly trees looked gray and were covered with a thin layer of dust from a nearby industrial zone. Unkempt grass, coated with the same dust, was bunched around the tombstones that remained upright. The dry season made the air still and hot.

A guard was seated on a broken cane chair at the entrance, smoking cigarettes and feigning indifference as our motorcade snaked inside. He rose to follow us. After our visit, the local police would require him to fill out a report. When I lit incense at a hulking, moss-covered concrete monument at the cemetery's highest point, I saw the guard hovering in the background. Attracted by the stir, onlookers had drifted in and were skulking by the gray trees.

Could this grubby, abandoned cemetery northeast of Hồ Chí Minh City really be a pivot point for reconciliation? Vietnam's Communist Party wanted it forgotten. Its graves contained soldiers who had fought for Saigon, and the government in Hanoi had let Biên Hòa Cemetery go to seed. Some feared that the cemetery could be a rallying point for those who opposed Vietnam's Communist Party.

The Vietnamese American community, whose members agreed on little else, was united on the importance of restoring Biên Hòa, of cleaning up its 
graves and honoring the souls buried there who had fought for South Vietnam. Community leaders, many based in Southern California, insisted that the cemetery be remembered and its dead treated with respect.

I had waited until I was halfway through my tenure as ambassador to visit the cemetery. A few years before, a South Vietnamese veteran piloted a small plane over Biên Hòa and dropped leaflets calling on the Vietnamese people to overthrow the Communist regime in Hanoi. I had needed to establish some credibility in Hanoi before I could make even a quiet visit to the cemetery. The government needed assurance that the American ambassador had no intention of destabilizing the fragile peace between north and south.

Months after I visited the cemetery, my husband, Clayton, and I were hosting an official dinner, and our honored guest was Drew Gilpin Faust, president of Harvard University. A distinguished historian of America's Civil War and its aftermath, Faust knew a lot about reconciliation.

"Biên Hòa Cemetery has symbolic importance," I said to her. "Properly burying the dead, in their homeland, matters to the Vietnamese, whatever part of the country they come from. But the government won't allow the Vietnamese American community to maintain it. What should I do?”

"After the U.S. Civil War," Faust replied, "it took a long time before Southern soldiers could be buried at Gettysburg. In cemeteries, the victors and the vanquished honor the dead and their sacrifice. But the victors choose who can be honored, and they may not show equal respect to those who fought on the losing side.

"Ambassador, let me offer a suggestion," she continued. "Instead of talking about 'The Dead,' with a capital T and capital D, try speaking instead about honoring people who died."

Faust was speaking from her seat in the grand dining room of the colonial mansion that served as the U.S. ambassador's residence. Pink and white flowers adorned the dining table, and each gold-rimmed plate was embossed with the Great Seal of the United States. Masterpieces from American photographers and Vietnamese artists adorned the walls. We were the sixth American family to occupy the stately home. In front of the building was an enormous American flag, while statues of Presidents George Washington and Abraham Lincoln watched over the back. It was fun to show it off.

Faust was seated next to Vietnam's deputy foreign minister, Lê Hoài Trung. I said to him, "A small gesture from the victors would mean a lot."

He shook his head. "This matter of Biên Hòa Cemetery is very difficult. People who oppose us have turned it into a political issue." Deputy Minister 


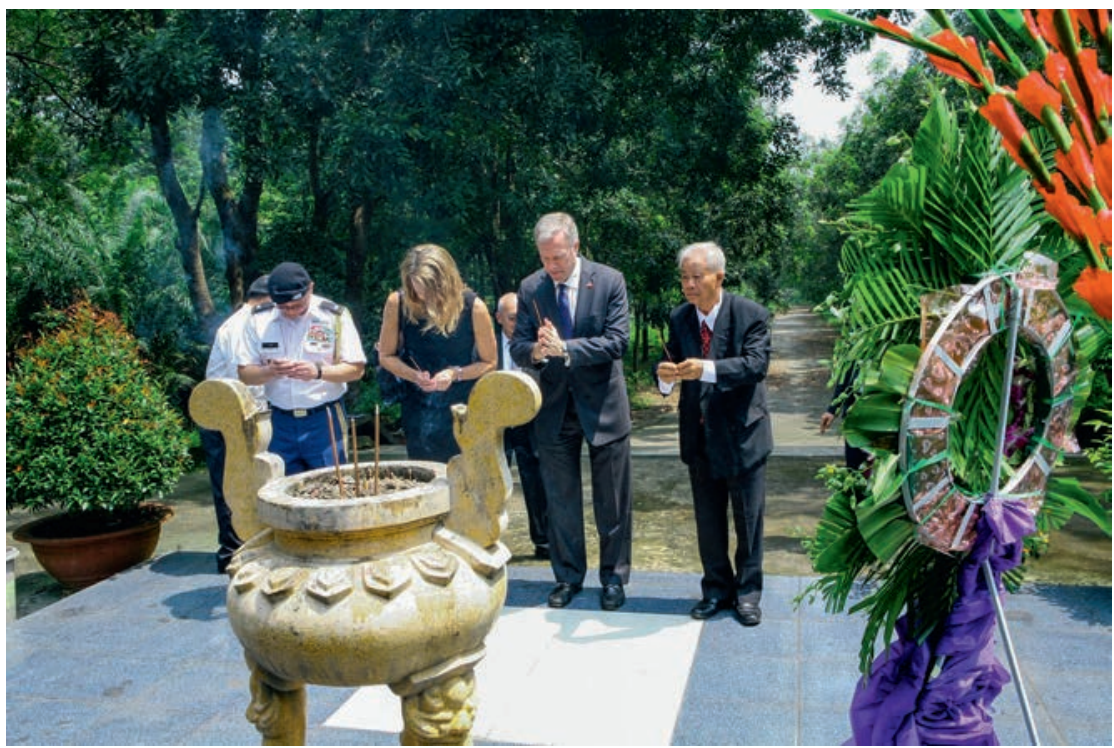

РH0T0 1 Colonel Tuấn T. Tôn; Consul General Mary Tarnowka; Ambassador Ted Osius; and Nguyễn Đạc Thành, president of the Vietnamese American Foundation, Biên Hòa Cemetery, Bình Dương province, October 2017 (Credit: Personal photos of Tuấn T. Tôn).

Trung remembered the pilot and his leaflets, as well as many attempts to raise the flag of South Vietnam in Biên Hòa.

Another guest, a former Việt Cộng guerrilla, Lê Minh Khuê, interjected, "According to Vietnamese tradition, death washes away all differences."

"Those with whom I have spoken only want to honor people who died," I told Deputy Minister Trung. "No capital letters. When the rainy season comes, they don't want the caskets to float away. They don't want tree roots to burst through the graves. No flags or symbols or politics," I promised. "Just two requests: let them dig ditches and cut tree roots."

He thought for a moment, then smiled: "Ditches and tree roots. Let me see what I can do."

Months after my ambassadorship ended, a friend wrote to me, knowing I still cared about Biên Hòa. He told me that ditches had been dug in the cemetery and tree roots had been cut. The rainy season had come, causing the trees to turn from gray to green. Death had washed away the differences. Reconciliation had progressed a meaningful step further.

When the Vietnam War ended with Saigon's fall on April 30, 1975, U.S. President Gerald Ford wanted Congress and the American people to shift their 
focus away from the chaos we had left behind. Henry Kissinger, Ford's secretary of state, rebuffed Vietnam's efforts to establish communication. Exhausted by the war and its damage to our own society, Americans didn't want to hear about Indochina. Veterans, activists, and Vietnamese refugees tried to bring attention to those left behind. As Vietnamese Americans in California, Texas, and Louisiana began to prosper and acquire some political clout, they insisted that their elected representatives pay attention to human rights and religious freedom in Vietnam, as well as to the treatment of buried soldiers who had fought for Saigon.

For twenty years, reconciliation between the governments in Washington and Hanoi progressed slowly. Only after President Bill Clinton established full diplomatic ties in 1995 did it appear possible that the United States and Vietnam could begin anew. Reconciliation involves deeply emotional matters, including honoring the dead with proper burials and acknowledging the pain and horrors of the war.

It depends on ties between people: the back-and-forth activities of businesspeople, student exchanges, tourists, and family visits. These ties continue to grow, because brave people from all sides decided to face the past squarely, build trust with former adversaries, and create a better future. They learned how to dig ditches and cut tree roots, to create the conditions for reconciliation one step at a time.

Nothing Is Impossible: America's Reconciliation with Vietnam is about that process, rooted in the tangible stories of some prominent individuals as well as ordinary citizens. Their stories show that friendship between old enemies is possible. A former prisoner of war, Pete Peterson, could serve as America's first postwar ambassador to Vietnam. Another former prisoner of war, Senator John McCain, and his ideological opponent, Senator John Kerry, could become champions of reconciliation. President Clinton, who dodged the draft, could help heal deep wounds.

As Washington and Hanoi were formally establishing ties, I requested an assignment as one of the first U.S. diplomats in a united Vietnam. It felt like a great stroke of luck to witness firsthand the early days of governmentto-government reconciliation.

Making friends in Hanoi, and later in Saigon, turned out to be remarkably easy. The Vietnamese people chose not to harbor grudges but rather to open their arms, even to representatives of a government that had waged a terrible war in their country. I had studied the Vietnamese language before my assignment began, and each time I met someone new during those heady early days, we built a bit more of the trust needed to create a partnership. 
I came to know the heroes who reconciled former adversaries: not only McCain and Kerry, but also former Vietnamese Foreign Minister Nguyễn Cơ Thạch and Vietnam's first ambassador to the United States, Lê Văn Bàng. I served on the staff of a true American hero, Ambassador Pete Peterson, who spent nearly seven years as a prisoner of war in the Hỏa Lò Prison (nicknamed the Hanoi Hilton) and then returned to that city as President Clinton's personal representative.

As a young political officer and later as ambassador, I collaborated with behind-the-scenes heroes of reconciliation, including Tommy Vallely, a Harvard professor; Virginia Foote, a trade expert; Tim Rieser, a Senate staffer; the Ford Foundation's Charles Bailey; Bùi Thế Giang, a member of Vietnam's Communist Party; diplomats Nguyễn Vũ Tú and Nguyễn Xuân Phong; and "superconnector" Thảo Nguyễn Griffiths.

Pursuing diplomacy with Vietnam for twenty-three years-under four presidents and seven secretaries of state-I became, in 2014, the first U.S. ambassador who spoke fluent Vietnamese, and the second openly gay career ambassador in U.S. history. When President Barack Obama visited Hanoi in 2016, he asked about my family. I offered to introduce him to my spouse, who is Black, and our children, who are of Mexican descent. Smiling, he referred to us as a "walking Benetton ad."

Becoming the U.S. ambassador to Vietnam was a dream come true. I love Vietnam. I love its people, history, language, and culture. During my first tour as a relatively junior diplomat in the 1990 os under President Clinton, we laid a foundation for a new relationship, and as ambassador under President Obama, I had the privilege of building upon that foundation. My history with the country helped me enjoy unstinting support from leaders in Washington and Hanoi, who shared the goal of making our new partnership work. The United States pushed the process of reconciliation through joint action with the Vietnamese on multiple fronts.

President Obama and Secretary of State Kerry provided a vision for transforming U.S.-Vietnam relations that I believed in passionately. While I served as ambassador, I was honored to host many U.S. visitors to Vietnam, including Supreme Court Justice Ruth Bader Ginsburg, President Clinton, the actors Samuel L. Jackson and Brie Larson, Nobel Prize winners, cabinet officials, members of Congress, and activists of all kinds.

Traveling to Vietnam with President Clinton in 2000, working as a diplomat in Asia during the administration of President George W. Bush, and hosting President Obama in Vietnam in 2016, I witnessed the power of a U.S. president's showing respect and how that builds trust and creates partnership 


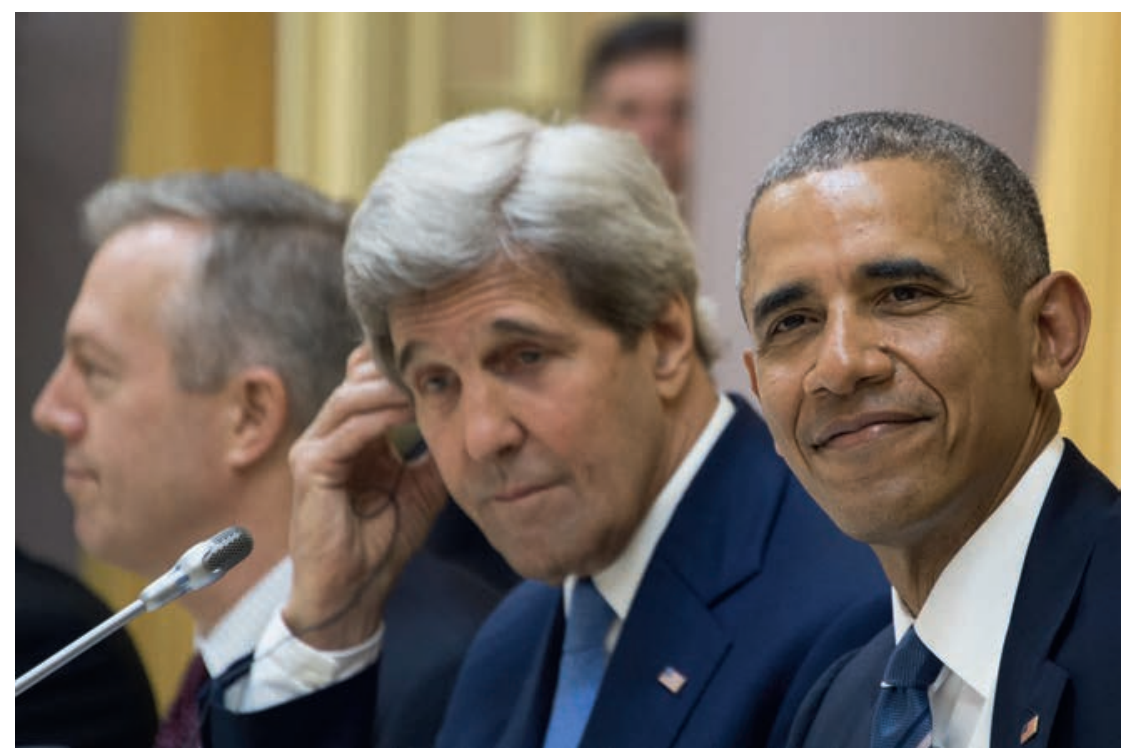

РнОт0 2 The author, Secretary of State John Kerry, and President Barack Obama, Hanoi, May 2016 (Credit: AFP/Jim Watson).

with former adversaries. In India, President Bush's commitment to a new partnership altered the trajectory of history. In Indonesia, I witnessed a transformation of relations under President Obama's leadership. As ambassador in Hanoi, I had the privilege of arranging the first visit to the Oval Office by Vietnam's Communist Party chief and of persuading President Obama to visit Hanoi and Hồ Chí Minh City. Presidents Clinton, Bush, and Obama understood the value of real partnerships for the United States.

Early in my tour as ambassador, Vietnam's press dubbed me "the People's Ambassador." I spoke Vietnamese and rode a bicycle everywhere, and that helped me make friends with citizens from all walks of life. On a bike and up close, I saw how Vietnamese turned their country from a ravaged war zone into a strong, prosperous, and independent friend of the United States. PBS News Hour broadcast a profile of me titled "Meet Bicycle Diplomat Ted Osius, America's Modern Ambassador to Vietnam."

On bicycles and in our travels, my embassy team and I learned important lessons about reconciliation. The war had left massive scars. Our only chance to shape a different future was by being honest about our history. And there are many versions of that history. As Ken Burns and Lynn Novick said in their documentary The Vietnam War, "There is no single truth in war." 
We learned that the United States casts a long shadow. Showing respect meant figuring out what was truly important to our Vietnamese partners and taking that seriously. We learned the lesson of ditches and tree roots. To build trust required efforts large and small. U.S. military and civilian leaders understood that ties between Vietnam's armed forces and the U.S. military would help advance America's security goals in the Asia-Pacific. My job, and that of my team, was to figure out how to build enough trust to allow those ties to develop. We had to remember that many of Vietnam's current leaders had come up through the ranks while fighting against the United States. Applying the ditches and tree roots concept-that is, one step at a time builds trust-was the only way to go. It required patience and determination.

Step by step, by finding the remains of soldiers who perished, destroying unexploded bombs, cleaning up Agent Orange, and assisting Vietnamese with severe disabilities in provinces that were heavily sprayed with the defoliant, Americans and Vietnamese built a foundation of trust that allowed them to become close security partners. The stories in this book show that when the United States commits itself to strong relationships, we create opportunities for a more prosperous and safer America. America's relationship with Vietnam has arisen from the ashes of war and become something unique. Our countries' remarkable transformation from enemies to friends shows that, truly, nothing is impossible. 
